\title{
脳性麻痺における外反母趾に対する観血的治療経験
}

\author{
鹿児島県立整肢園 \\ 山 浦 一 郎·肥 後勝 \\ 牟田實・岡 野 奈津子
}

\section{Operative Treatment for Hallux Valgus in Cerebral Palsy}

\author{
Ichiro Yamaura, Masaru Higo, Minoru Muta, \\ and Natsuko Okano \\ Kagoshima Prefectural Crippled Children's Hospital
}

\begin{abstract}
Ten feet of seven patients with cerebral palsy were surgically corrected for hallux valgus deformity. All patients were ambulatory, and all had symptomatic bunion and hallux valgus deformities before surgery. The mean age of the patients at the time of surgery was 13.8 years (range; 10-18 years). The mean age of the patients at the time of follow-up was 20.7 years (range; 13-25 years). The mean hallux valgus angle was $28^{\circ}$ preoperatively, and $1^{\circ}$ postoperatively. The operative procedure consisted of distal first metatarsal osteotomy, adductor hallucis muscle transfer, and soft tissue release. Postoperatively, all patients had no pain, and hallux valgus deformities were adequately corrected in six feet, however, varus deformities of hallux were seen in four feet. On two of the four feet, tenotomy and transfer of abductor hallucis muscle were performed and they now have good results with no pain. Apparently spasticity of the abductor hallucis muscle causes varus deformity of the hallux after adductor muscle transfer.
\end{abstract}

Key words : Cerebral palsy (脳性麻瘏), Hallux valgus (外反母趾), First metatarsal osteotomy（第一中足骨骨切り術）

\section{はじめに}

脳性麻瘦においては，痓性と筋の不均衡に起因して 種々の足部変形が生じるが, 外反母趾変形は進行する と疼痛, 胼胝形成を伴い, 荷重歩行の大きな障害とな る.

今回我々は, 合併した他の足部変形とともに, 外反 母趾変形に対する観血的治療を行い，その手術成績に ついて検討した。

\section{対象症例と方法}

対象症例は当園にて加療した脳性麻痺患者 7 例（男： 4 例, 女: 3 例) 10 足であり, 脳性麻痺型は㾏直型両 麻瘦 6 例, 㽷直型三肢麻痺 1 例である. 術前全例が歩
行可能であり, 外反母趾変形, 第一中足趾関節部の胼 胝形成，疼痛を認めた．合併してみられた足部変形は 外反扁平足 6 足，外反尖足 4 足であった。手術時年齢 は $10 \sim 18$ 歳 (平均 13.8 歳), 調查時年齢は $13 \sim 25$ 歳 (平均 20.7 歳), 術後経過観察期間は $2.7 \sim 10.7$ 年 (平均 6.8 年) であった。

外反母趾変形に対する手術方法は, Mitchell ${ }^{5)}$ 法に よる第一中足骨骨切り術，母趾内転筋移行術，内側関 節包縫縮術などを併用し，変形矯正した。

外反偏平足を合併し変形が高度であった 6 足に対し $\mathrm{Grice}^{2)}$ 手術，および長・短腓骨筋腱延長術を同時に 行い，外反尖足を認めた 4 足に対してはアキレス腱延 長術を同時に行った。また, 追加手術として, 術後早 期に内反変形がみられた 2 足に対し， 1 足には母趾外 


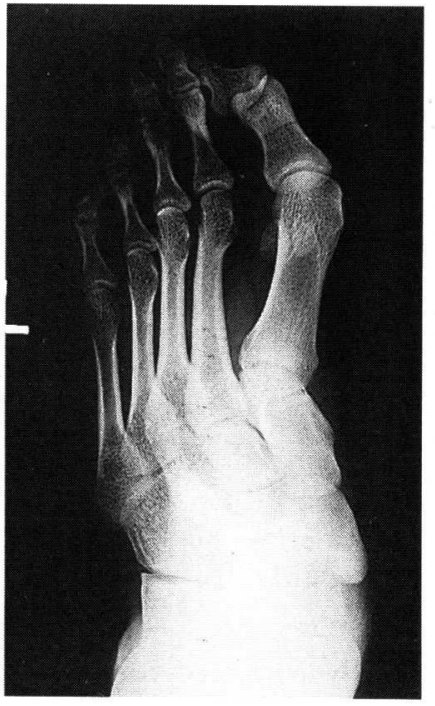

a

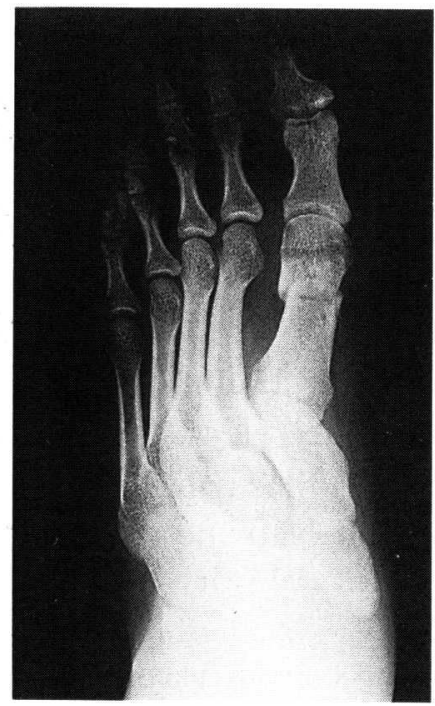

b

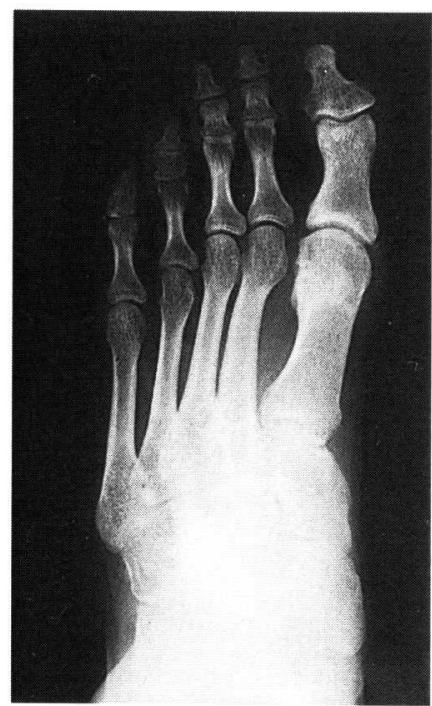

c

図 1 症例 18 歳 男性病直型両麻瘏 左足部 X-P

a）左外反母趾変形を認め, 術前の $\mathrm{HV}$ 角は $37^{\circ}, \mathrm{M}_{1}-\mathrm{M}_{2}$ 角は $10^{\circ}$ であった.

b）外反母趾手術後 6 週, 外反母趾変形矯正と骨切り部の骨瘑合を認める.

c) 術後 4 年 3 カ月の調查時, 外反母趾は消失し, HV 角は $10^{\circ}, \mathrm{M}_{1}-\mathrm{M}_{2}$ 角は $2^{\circ}$ と改善した.

転筋移行術を行った。

臨床成績は Glynn ら ${ }^{11}$ の成績判定基準を用い，X 線学的評価は荷重時の足部背底 X 線像における外反 母趾角 (以下 $\mathrm{HV}$ 角)，第一。二中足骨間角 (以下 $\mathrm{M}_{1}-\mathrm{M}_{2}$ 角）を計測し，手術による改善度を検討した。

$$
\text { 結果 }
$$

術前にみられた第一中足趾関節部の胼胝形成，疼痛 は調査時には全例消失しており, 臨床成績は Glynn らの判定基準によると, excellent 7 足, good 1 足, unsatisfactory 2 足であり, excellent 7 足中, 1 足 は母趾外転筋解離術を, 1 足は母趾外転筋移行術を追 加して行った症例であった. Unsatisfactory となっ た 2 足には母趾内反変形を認めていた.

$\mathrm{X}$ 線学的には, 関節症性変化は全例認めず, HV 角 は術前平均 $28.3^{\circ}$, 術直後平均 $1.7^{\circ}$, 調査時平均 $0.7^{\circ}$ であり, $\mathrm{M}_{1}-\mathrm{M}_{2}$ 角は, 術前平均 $12.3^{\circ}$, 術直後平均 $4.2^{\circ}$, 調査時平均 $4.9^{\circ}$ と術後に改善がみられていた。

\section{症 例 供 覧}

18 歳男性 痤直型両麻痺. 左外反扁平足, 左外反
母趾変形, 第一中足趾関節部の胼胝形成, 疼痛を認め, 術前の HV 角は $37^{\circ}$ であった（図 1a). Grice 手術 と同時に外反母趾手術を施行した。術後, 外反母趾は 矯正され，骨切り部の骨癒合も得られた（図 $1 \mathrm{~b}$ )。術 後 4 年 3 力月の調查時, 胼胝形成や疼痛はなく, $\mathrm{X}$ 線上, 母趾に変形はなく, HV 角は $10^{\circ}$ と改善がみら れ, Glynn 判定基準では excellentであった（図 1c).

考察

脳性麻痺にみられる足部変形は股関節, 滕関節の変 形と同様に筋のバランスの不均衡により生じ, 種々の 変形がみられる. 外反母趾変形は, 進行すると縦アー 千破綻の一因となり, 荷重バランスに対する障害とな るばかりでなく胼胝形成, 疼痛などを引き起こし, 荷 重歩行の妨げとなる.

脳性麻瘏における外反母趾の治療について Renshaw $ら^{6)}$ は, 第一中足趾関節固定術は母趾の安定性をもた らし, 変形の再発を起こしにくい有効な手術法である としている。一方, Jenter ら ${ }^{3)}$ は, 第一中足骨, 第 一基部節骨骨切り術に軟部組織解離術を併用すること により関節固定術と同等の良好な成績が得られたと報 
告している.

今回我々は，一般の外反母趾治療において安定した 成績が得られている Mitchell 法による第一中足骨骨 切り術に軟部組織解離術を併せて行ったが, 術後 10 足中 4 足に母趾内反変形が認められた。追加手術を施 行した 2 例の手術時所見は 2 例共に母趾外転筋の高度 緊張が認められており, 母趾内転筋移行術を施行した ことにより母趾外転筋が相対的な過緊張となり内反変 形を起こしたものと考えられた。追加手術を行った 2 例に変形の再発は認めていない.

松尾 ${ }^{4)}$ は脳性麻痺における外反母趾変形の発症因子 として長母趾屈筋, 短母趾屈筋, 母趾内転筋の関与を 指摘している. 第一中足骨骨切り術に軟部組織解離術 を併用した方法で確実な変形矯正を行うためには，足 関節内反筋, 外反筋や母趾外転筋を含めた筋均衡獲得 が特に重要であると考えられ, 術後経過観察中に母趾 内反変形がみられた際には，母趾外転筋解離術もしく は移行術を追加することが有効な手段であると考えら れた。

\section{結語}

(1)脳性麻痺の外反母趾 10 足に, 第一中足骨骨切り 術と軟部組織解離術を併用し，6足に良好な矯正が得
られた。

(2)術後経過観察中, 4 足に母趾内反変形を認めた.

(3)母趾内反変形は母趾外転筋の過緊張によるものと 考えられ, 外転筋解離術, 移行術の追加が有効であっ た。

\section{参 考 文 献}

1) Glynn, M.K., Dunlop, J.B., Fitzpatrick, D.: The Mitchell distal metatarsal osteotomy for hallux valgus. J. Bone Joint Surg., 62-B : 188-191, 1980.

2) Grice, D.S.: An extra-articular arthrodesis of the subastragalar joint for correction of paralytic flat feet in children. J. Bone Joint Surg., 34-A : 927-940, 1952.

3) Jenter, M., Lipton, G.E., Miller, F.: Operative treatment for hallux valgus in children with cerebral palsy. Foot Ankle, $19: 830-835,1998$.

4) 松尾 隆: 脳性麻痷の整形外科的治療, pp.147-174, 創風社, 1998.

5) Mitchell, C. L. et al.: Osteotomybunionectomy for hallux valgus. J. Bone Joint Surg., 40-A : 41-58, 1958.

6) Renshaw, T.S., Sirkin, R. B., Drennan, J.C.: The management of hallux valgus in cerebral palsy. Develop. Med. Chilid Neurol., 21 : 202-208, 1979. 